\title{
Worldview and Behavioural Study of Sports from the Islamic Perspective among Sports Officials in Malaysia
}

\author{
Badlihisham Mohd Nasir ${ }^{1}$ \\ Yusaini Yusof2 \\ Kamaruzzaman Yusoff ${ }^{1}$
}

Abdul Hafidz Omar ${ }^{3}$

Abdul Ghafar Don²

Berhanundin Abdullah 4

Mohd Fauzi Abu@Hussin1

Hussin Salamon ${ }^{1}$

\section{Ahmad Muhyuddin Hassan ${ }^{1}$}

Akmaliza Abdullah1

\section{Ahmad Syukran Baharuddin ${ }^{1}$}

\author{
${ }^{1}$ Faculty of Islamic Civilisation, Universiti Teknologi Malaysia, Skudai, Johor, Malaysia \\ ${ }^{2}$ Faculty of Islamic Studies, Universiti Kebangsaan Malaysia, Bangi, Selangor,Malaysia \\ ${ }^{3}$ Department of Biosciences and Health Sciences, Faculty of Biomedical Engineering and Health Sciences, \\ Universiti Teknologi Malaysia, Skudai Johor, Malaysia \\ ${ }^{4}$ Universiti Sultan Zainal Abidin, Gong Badak, Kuala Terengganu, Terengganu, Malaysia
}

Doi:10.5901/mjss.2016.v7n1p555

\section{Abstract}

\begin{abstract}
A person's worldview provides a structure to his thoughts and actions. Personal experiences, different kinds of cultural influences, the environment and personal reflections shape a person's worldview and affects how he perceives and interprets the world around him and thus influences his behavioural pattern. This study was conducted to explore the understanding of officials at the Ministry of Youth and Sports in Malaysia regarding sports from an Islamic worldview and its influence on their behaviour. An instrument, modified from past researches and verified by a panel of experts which attained a considerable level of alpha Cronbach value, was used to measure understanding and behaviour of 349 sport officials obtained through simple random sampling method. The instrument encompassed the domains of faith (aqidah), worship (ibadah) and morality (akhlak) with regard to rulings, regulations and goals in sports from an Islamic worldview. Data were analysed through correlation, $T$ test, ANOVA and Simple Regression statistical analysis. Results obtained indicated a high level of understanding of sports from an Islamic worldview. There were significant difference in understanding Islamic worldview based on level of education and grade obtained in the subject of Religious Education. Furthermore, these two variables showed a high positive correlation between the domains of worldview and behaviour among the respondents. However, there was no significant relationship between understanding and behaviour based on type of school stream and length of service. This study implies that an understanding of sports from an Islamic worldview has an influence on the willingness of officials in the Ministry of Youth and Sports in Malaysia to implement shariah compliant sports.
\end{abstract}

Keywords: Islamic worldview, Health, Sports, Behaviour, Shariah compliant sports

\section{Introduction}

A worldview refers to a set of beliefs about fundamental aspects of life that shapes and influences at how one perceives, thinks and acts. It is affected by a number of factors, namely, a person's inherent characteristics, cultural and religious 
background, life experiences and situations; values and attitudes. From an Islamic perspective, a worldview or tasawwur is a comprehensive conception of the universe and man's relation to it as defined by Islamic tenets thereby serving as a basis for one's philosophy or outlook on life. According to al-Ghazali (1939), knowledge and actions are inescapably linked together where true knowledge guides man to regulate the balance between lust and faith in Allah and a person thoughts and reasoning are reflected in his behaviour and actions.

Given that Islam encompasses all aspects of life of its adherents, invariably sports and the way sports is conducted too is governed by Islamic ethics and principles. Therefore, a correct understanding of sports from an Islamic worldview is essential to ensure that its practice is in line with Islamic teachings and any contradictions to Islam in the way sports is conducted, for instance, the wearing of charms, exposing of aurah, gambling, violence, fights, verbal abuse, use of drugs, corruption, fraud, and sexual harassment prevalent in modern sports (Abdul Hafidz, 2000) are frowned upon by Islam. The nature of modern sports is secular and some of its aspect are not acceptable in Islam (Allen Guttmann in Uriya Shavit \& Ofir Winter, 2011). Hence, a clear understanding of the Islamic worldview or tasawwur is important as a clear worldview will serve as a guideline or parameter as to how life which is harmonious to Islamic ethics is conducted and thus shape behaviour.

In Malaysia, sports is not only competitive but it has also become a leisurely pursuit for a healthy lifestyle (Mohd Salleh, 2004). However, some practices contradictory to Islamic teachings are rife in sports and this raises the question over, firstly, the level of awareness of the public, particularly sports officials, over the conflict between current practices in sports and Islam and secondly, the willingness of these officials to attune the current sports system with stipulations in Islam that aim to preserve human dignity and uphold harmony.

Social cognitive theory states that personal events influence personal processes and subsequent behaviour (Bandura 1977, 1991). To explore how cognition affects behaviour, a study conducted by Torres et.al (2006) on public perception and understanding of behaviour towards agricultural biotechnology was examined. He found that worldviews, values and source of information influenced understanding, perception and behaviour. Azhar Ahmad (2006) conducted a study on self-regulation strategies for learning Islamic education and moral appreciation among high school students in the state of Sarawak. His study confirmed the relationship between worldview and behaviour. Self-regulation is a metacognitive process that involves planning, ordering, self-direction and self-assessment in various stages of the learning process (Zimmerman 1989a, 1994). In the context of Islamic education, skills developed through self-learning helped students grasp key goals of Islamic education and shape their moral character as well as prepare individual to face life challenges (Aisha Lemu 1991; Za'ba 2005 in Azhar Ahmad 2006).

Absence of religious knowledge has a negative impact on positive character building and a strong understanding of Islamic teachings and worldview results in nobel outcomes on behaviour. Hence to attain good moral character one must acquire knowledge (Al-Ghazali 1939). The basis of al-Ghazali views were based on verses of the Qur'an and the sayings of the Prophet Muhammad (saw) that links knowledge, understanding and reasoning with good character and behaviour.

"Do not follow what you have no knowledge" (al-Isra: 36). In this verse, the word 'follow' is the behaviour and the word 'knowledge' implies worldview or tasawwur. In a hadith, the Prophet SAW said, "Say: I believe in God then to be continued" (al-Muslim, 1960). In this hadith, the word "believe" is the understanding of the aspirations of Islam and the word "to be continued" is behaviour. It is therefore reasonable to state that Islamic and Western scholars agree on the influence of cognition on behaviour. Based on this understanding and upon the model proposed by Torres et al (2006) and Albert Bandura $(1986,1991)$, this study applied the model in Figure 1.

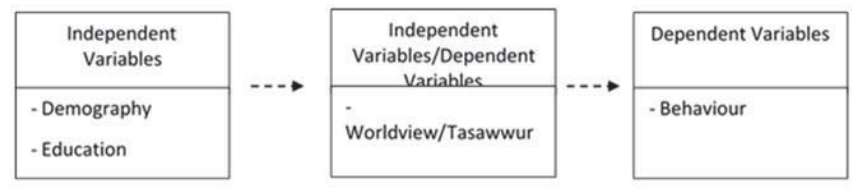

Relationship between the variables.

Figure 1: Model of the study in general (Model modifications from Torres et.al 2006).

Variables of Islamic worldview and its relation to behaviour in this study are adaptations and modifications of models of intruments obtained from a research conducted by Azma Mahmood (2005) in The Moslem Attitude Toward Religion Scale (Wilde \& Joseph, 1997), Sahin-Francis Scale of Attitude Towards Islam (Sahin \& Francis, 2002), Psychological 
Centrality Scale of Religion (Prezyna, 1977), Gladding Scale of Religiosity (Gladding et al., 1981) and Francis Scale of Attitude Towards Christianity (Francis, 1989). Elements of Islamic worldview in sports in this research are faith, worship and morality and its relationship to behaviour.

According to Azma Mahmood (2005), aspects of faith include elements in the Islamic Pillars of Faith while aspects of worship are elements contained in the Pillars of Islam. He has also divided moral values into five components which comprised self, family, community, nation and the environment. This division has similarities with the work of Darrāz (1987) who categorized Islamic moral divisions into five parts, namely individual, family, community, nation and religion. Many writers have discussed on rules, regulations and goals in sports according to Islam (al-Qaradhawi (undated); Abdul Hafidz 2000a, 2000b; Ali Husayn 2003; Mohammad Abouzied 2003; Ibn.Taimiyyah and Ibn.Qayyim in Ibn.Ktlan 2007 and Ibn. Saqr $(2009,2010)$ and all agree that negative practices for instance betting, bribery and deceit in sports are forbidden in Islam and the goals of sports are to forge harmony, friendship and health.

Based on the above discussion, the main objective of the study was to determine the level of understanding of Islamic worldview as regards to sports among Muslims sports officials in the Ministry of Youth and Sports in Malaysia and their willingness to conduct shariah compliant sports based on level of educational, secondary school stream, grade obtained in the subject of Religious Education and length of service. Figure 2 below depicts the conceptual framework of this study.

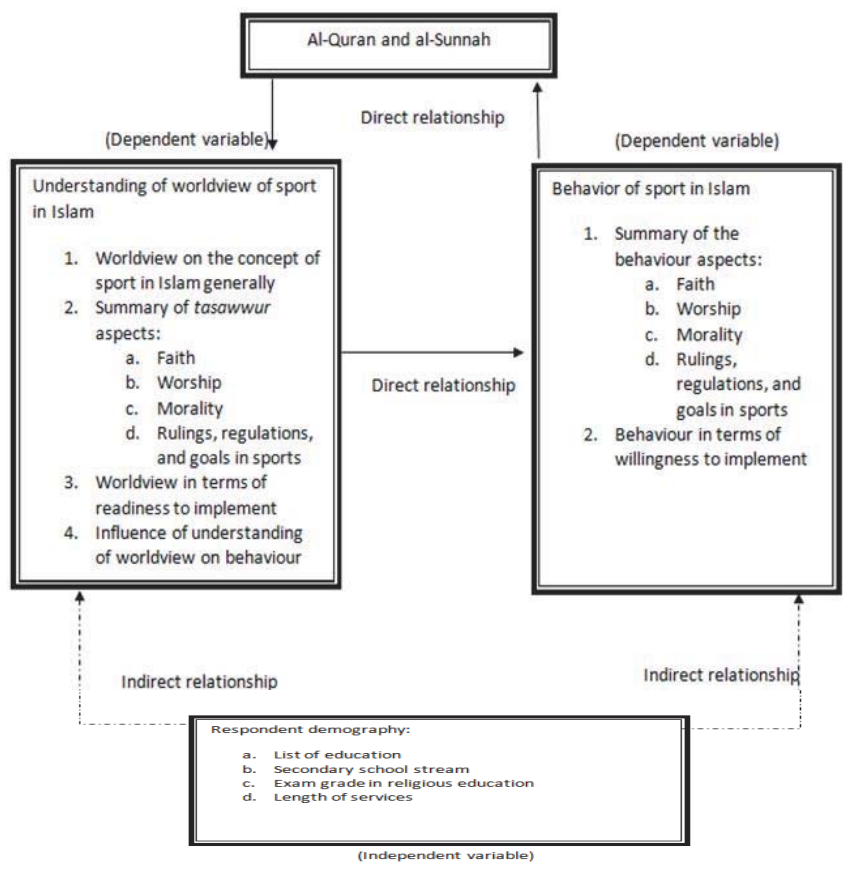

Figure 2: The conceptual framework of understanding the worldview and behaviour among the Muslims sports officials in the Ministry of Youth and Sports.

\section{Methods}

This study was conducted among Muslim sport officials that have attained puberty employed at the Ministry of Youth and Sports Malaysia at federal and state level. According to Abdullah Nasih (1995), at the age of puberty, set at over 15 years of age, respondents are assumed to be able to assess themselves in terms of comprehension for Islamic faith, worship and morality. A total of 349 people were taken as sample from a population of 3,400 people (Human Resources Division KBS). The sample ratio to population was suggested by Krecjie \& Morgan (1970).

The sampling method used to select the sample in this study was a simple random sampling technique. The percentage ratio of all the samples to strata titles is high and exceeded the minimum requirements for each population 
sample ratio according to Sekaran (2003) which was 30 to 50 people for each stratum. Borg and Gall (1979) suggested that in a survey, sub main small group should contain at least between 20 to 50 subjects each. A breakdown of sample based on gender and highest attained level of education is shown in Table 1.

Table 1: Breakdown percent level of educational attainment by gender

\begin{tabular}{|c|c|c|c|c|}
\hline \multirow[t]{2}{*}{ Strata } & & \multicolumn{2}{|c|}{ Gender } & \multirow[t]{2}{*}{ Total } \\
\hline & & Male & Female & \\
\hline \multirow{4}{*}{ Level of education } & SRP & 2 & - & 2 \\
\hline & SPM & 35 & 44 & 79 \\
\hline & Diploma & 101 & 66 & 167 \\
\hline & Degree & 72 & 29 & 101 \\
\hline Total & & $210(60.2 \%)$ & $139(39.8 \%)$ & $349(100 \%)$ \\
\hline
\end{tabular}

A four-part set of questionnaire, adapted and modified from Azma (2005), Nima Jahtae (2005), Mohd. Nizam (2007) and Ali Tekin (2010), was used to collect data. It comprised of demographic assessment of sample, items measuring an understanding of sports from an Islamic worldview which comprised elements of faith, worship and morality and items measuring behaviour in terms of willingness of respondents to implement sports compatible with Islamic worldview. Respondents are also encouraged to post suggestions and comments on the subject matter.

All data was processed and analyzed through the Statistical Package for the Social Sciences (SPSS) for Windows version 16.0. Two types of analysis were conducted to obtain descriptive analysis (frequency, percentage and mean scores) and inferential analysis. Inferential statistics performed were independent-samples T-test, ANOVA (One-Way Analysis of variance), Pearsons's correlation Product Moment and simple regression equation (simple regression).

\section{Results and Discussion}

Table 2 presents the demographic characteristics of this study. The age range of the respondents were between 21 to 60 years with the majority aged between 31 to 40 years (34.1\%). Most respondents had attained a diploma in education and a majority had obtained high grades for Religious Education in their exam.

Table 2: Demographic characteristics

\begin{tabular}{lcc}
\hline Variable & Frequency & $\%$ \\
\hline Gender & & \\
Male & 210 & 60.2 \\
Female & 139 & 39.8 \\
\hline Level of education & & \\
High school & 81 & 23.2 \\
Diploma & 166 & 47.6 \\
Degree & 102 & 29.2 \\
\hline Secondary school stream & & \\
Religious & 30 & 8.6 \\
Non-religious & 319 & 91.4 \\
\hline Exam result For Religious Education & & \\
Excellent & 197 & 56.4 \\
Pass & 152 & 43.6 \\
\hline Length of service & & \\
0 to 5 years & 139 & 39.8 \\
6 to 10 years & 90 & 25.8 \\
11 to 15 years & 32 & 9.2 \\
16 to 20 years & 22 & 6.3 \\
21 to 25 years & 15 & 4.3 \\
26 to 30 years & 24 & 6.9 \\
31 to 35 years & 27 & 7.7 \\
\hline Total & 349 & 100 \\
\hline
\end{tabular}


Results of the study indicated that the level of understanding of sports from an Islamic worldview with regards to faith, worship and morality among the respondents were high (Norasmah, 2001; Azhar, 2006). The values obtained for each aspect was; $\min =4: 49, \mathrm{sp}=0.34$ (tasawwur of faith), mean $=4.29, \mathrm{sp}=0.41$ (tasawwur of morality), mean $=4.14, \mathrm{sp}=$ 0.39 (tasawwur of worship). Results are shown in Table 3 below.

It was found that respondents had the highest mean scores on understanding worldview with regards to faith, followed by morality and lastly worship. Overall mean for understanding the worldview with all aspects with regards to faith, worship and morality were high (mean $=4.31, \mathrm{sp}=0.32$ ).

Table 3: The level of understanding of Islamic worldview on sport in general

\begin{tabular}{lccc}
\hline Aspects of worldview & Mean & Sd & Level of understanding \\
\hline Faith & $4: 49$ & 0.34 & High \\
Worship & $4: 14$ & 0.39 & High \\
Morality & 4.29 & 0.41 & High \\
\hline
\end{tabular}

In order to compare if there are differences in understanding Islamic worldview on sports based on several demographic variable, t-test and one way ANOVA were conducted. Results indicated that grade in the subject of Religious Education (Table 4) and levels of education (Table 5) made a difference on understanding the Islamic worldview. On the other hand, school stream and length of service did not show significant differences in understanding this concept.

Table 4: T-test result on differences in understanding worldview based on grade in the subject of Religious Education

\begin{tabular}{lcccccc}
\hline Grade & $\mathrm{N}$ & Mean & $\mathrm{Sd}$ & $\mathrm{df}$ & $\mathrm{t}$ & $\mathrm{p}$ \\
\hline Excellent & 197 & 4.36 & 0.29 & 347 & 3.768 & 0.004 \\
Pass & 152 & 4.23 & 0.34 & & & \\
\hline
\end{tabular}

Table 5: Result of one way ANOVA on differences in level of understanding based on level of education

\begin{tabular}{lccccc}
\hline Sources of variance & Sum of squares & df & Mean square & $F$ & $p$ \\
\hline Between group & 1.640 & 2 & 0.820 & 8.137 & 0.000 \\
Within group & 34.872 & 346 & 0.101 & & \\
Total & 36.512 & 348 & & & \\
\hline
\end{tabular}

An analysis was also conducted to measure the level of willingness among respondents to implement shariah compliant sports. Table 6 below shows the general behaviour of sports in Islam with regards to faith, worship and morality. Mean values obtained for each aspect were; morality, mean $=4.35, s p=0.45$, worship, mean $=4.28, s p=0.49$ and faith, mean $=4.20, \mathrm{sp}=0.36$. Thus, respondents in the study had high levels of willingness to implement sports compatible to Islam from the aspect of faith, worship and morals (Norasmah 2001; Azhar 2006). These findings are similar to the findings obtained by Azhar (2006). Thus a sufficient understanding of Islamic worldview in the aspects of the faith, worship and morality affected behaviour as suggested by Islamic scholars like Imam al-Ghazali.

Table 6: Level of willingness to implement shariah compatible sports

\begin{tabular}{lccc}
\hline Aspects of worldview & Mean & Sd & Level of understanding \\
\hline Faith & $4: 20$ & $0: 36$ & High \\
Worship & $4: 28$ & $0: 49$ & High \\
Morality & $4: 35$ & $0: 45$ & High \\
\hline
\end{tabular}

To study the relationship between understanding the worldview and willingness to implement Islam compliant sports, an analysis of Pearson product moment correlation was conducted. Result showed a significant positive relationship between understanding and behaviour $(r=0.693, p<0.05$. The high value of $r=0693$ (Elias 1999; Pallant 2001; Norasmah 2001; Jackson 2006) implied that the higher the level of understanding of the tasawwur, the higher the willingness to implement Islam compliant sports. Table 7 presents the result of the correlation between the two domains. 
Table 7: Result of Pearson correlation between understanding and willingness

\begin{tabular}{|c|c|c|c|c|c|c|}
\hline Variable & $\mathrm{N}$ & Mean & $\mathrm{Sd}$ & $r$ & $\mathrm{R}^{2}$ & Sig \\
\hline Level of understanding & 349 & 4.31 & 0.32 & $0.693^{\star \star}$ & 0.693 & 0.000 \\
\hline Level of willingness & 349 & 0.39 & 4.28 & & & \\
\hline
\end{tabular}

** Sig. at the level of 0.01

This finding suggested that understanding played an important role in human development and it can strengthen and stabilize human emotions to deal with bias behaviours (Ibn Khaldun 2002; al-Qaradawi 1990; al-Ghazali 1939).

To test the influence of understanding on behaviour, a simple regression test was conducted and the result of the analysis is presented in Table 8. It was found that the variance of tasawwur in general contributed significantly on staff behaviour, the value of $F=320.039$ and significantly value $=0.000(p<0.05)$, the value of Beta $=0.693, t=3.199$ and Sig $=0.002$ and $\mathrm{R}^{2}=0.480$. The findings showed that $48 \%$ of general variables affecting tasawwur, contribute or influence behaviour in general on KBS staff (Hair et al. 2006; Pallant 2001). The conclusion to be drawn from the findings of this regression is, when a variable of worldview or tasawwur in general increase a unit, scores on behaviour in general will

Table 8: Result of Simple Regression

\begin{tabular}{lccccccc}
\hline Variable & $\mathrm{B}$ & Error & Beta & $\mathrm{t}$ & $\mathrm{Sig}$ & $\mathrm{R}^{2}$ & Contribution \\
\hline Behaviour in general & 0.651 & 0.203 & 0.693 & 3.199 & 0.002 & 0.480 & $48 \%$ \\
Constant & 0.843 & & & 17.890 & 0.000 & & \\
\hline
\end{tabular}

Dependent Variable: Behaviour in general

Results of this study provides an insight for those involved in the development and implementation of sports in Malaysia. These findings indicated that understanding of Islamic worldview through formal learning plays a very important role in development of a virtuous man. This is perceived when level of education and good grades in the subject of Religious Education showed significant differences in understanding the worldview, behaviour and overall readiness to implement sport harmonious with Islam. Hence, formal education in Islamic studies must be supported and given due consideration by interested parties to ensure that aspirations to conduct sport practices that are compliant to Islamic teachings comes to fruit.

\section{Implications of the Research}

1. This study, which employed an empirical, comprehensive and integrated method to explore the possibility of implementing sports which is compatible to Islam, will further trigger other studies specifically related to this subject.

2. The instrument in this study can be used by the Ministry of Youth and Sports to assess the level of understanding and willingness to implement sports which is compatible to Islam among ministry staff.

3. The results of the study indicated a positive relation between understanding and willingness to implement sports compatible to Islam with level of education and prior education in Islamic studies. This draws attention to the importance of education in enhancing understanding and change in behaviour among policy makers and the public in general over the above issue.

4. Information and profile of respondents obtained from this study is useful to KBS in particular and the government in general for further research and action.

\section{Conclusion}

This study aimed to present a sports concept from an Islamic perspective. Three main concerns of sports according to the Islamic concept are its rulings, regulations and goals. It is seen from three main aspects in the framework of the Islamic worldview that is faith, worship and morality. Results obtained through this study indicated that officials employed by the Ministry of Sports in Malaysia had a high level of understanding of sports from an Islamic perspective and had a high level of willingness to implement sports that is compatible to Islamic tenets. Thus, policy makers involved in sports should strategise and design an integrated plan to ensure that all personnel acquire a clear understanding of the concept of sports according to Islam and implementation of sports practices which are compatible to Islamic teachings. This study 
may pave the way and become a catalyst towards a more concerted effort to conduct other researches related to this issue.

\section{References}

Al-Quran

Abdul Hafidz Haji Omar, 2000a. The Influence Of Culture On Muslim Athletes: A Case Study Of 1998 Malaysian Commonwealth Games Athletes. PhD thesis School Of Human Movement Studies, Faculty Of Health, Queensland University of Technology, Australia.

Haji Abdul Hafidz Omar.2000b.Striving For Balance: Modernity And Elite Sport From an Islamic Perspective. Penerbit Universiti Teknologi Malaysia Skudai.

Abdullah Nasih Ulwan. 1995. Education of children in Islam. Translated. Syed Ahmad Semait. Singapore: National University Press.

Husayn Ali Amin Yunus. 2003. al-Al'ab al-Riyadiyah. Dar al-Nafa'is.

Ary, D., Jacobs, L.C., \& Razavieh, A. 1996. Introduction To Research In Education. Orlando, Florida: Harcout Brace College Publishers.

Azhar Ahmad. 2006. Learning strategies and self-regulation of Islamic education and appreciation of high school students' behaviour. Ph.D. Thesis National University of Malaysia.

Azma Mahmood. 2005. Appreciation AMA Islamic Education High School Students In Malaysia.Tesis Ph.D. Faculty of Education, Universiti Kebangsaan Malaysia.

Human Resources Division Ministry of Youth and Sports Malaysia (KBS). Staff Statistics till December 2011.

Bandura, A. 1986. Social foundations of thought and action: A social cognitive theory. New Jersey: Prentice-Hall.

Bandura, A. 1991. Social cognitive theory of self-regulation. Organizational Behaviour and Human Decision Processes. 50: 248-287.

Berne, Eric. 1964. Games People Play: The Relationship of Human Psycology. New York: Ballantine Books.

Borg, W.R. \& Gall, M.D. 1979. Educational Research: An introduction. 3rded. New York: Longman Group Limited.

Darrāz, Muhammad cAbdullah. 1987. The moral principle based on the Qur'an. Translated. Abdul Fatah Ibrahim, Mohd Sulaiman Yasin, Wan Wan Yaacob Amna \& Abdullah Md Zin. New York: Routledge.

Al-Ghazali, Abu Hamid Muhamed bin Muhammad. 1997. Muslim faith. (Terj.). NY: Library thinkers.

Al-Ghazali, Abu Hamid Muhamed bin Muhammad. , 1939. Ihya 'al-Din culūm. Juz. 1. Misr; Matbacah Mustafa al-Bab al-Halabi.

Haron Din, Sulaiman Yasin Hassan Salleh \& Sidi Gazalba. 1988. Man and Islam. Kuala Lumpur: Watan Printing Sdn. Limited.

Jackson, S.L. 2006. Research methods and statistics: A critical thinking approach. USA: Thomson.

Johnson, B. \& Christensen, L. 2000. Educational research: Qualitative and quantitative approaches. Boston: Allyn and Bacon.

Ibn Khaldun, Abd al-Rahman ibn Khaldun al-Hadrami Muhammad. 2002. Narration of Ibn Khaldun. Terj.Dewan Prentice. New York: Routledge.

ibn. Ktlan, Said. 2007. Kinds of competition and Provision in the law. http://rwllh.com/vb/showthread.php (12 April 2011).

Mohammad Abouzied. 2003. Sports in Islam AIMS to force. http://www.egyptiantalks.org/invb/index.php?showtopic=4230 (12 March 2011).

Mohd. Salleh Aman. 2004. Sport In Society Malaysia. Kuala Lumpur: University of Malaya Publisher.

Mohd Salleh Aman. 2005. Basic Sports Management. Kuala Lumpur: University of Malaya Publisher.

al-Muslim. , 1960. al-Jami 'al-sohih, Min Mukhtasar Sharh al-Nawawi Ghairih WA. Juz. 6. Egypt: Syarīkatu WA Ma(tba'at Mustafa al-Bab al-Halabi.

Norasmah Othman. 2001. Effectiveness of youth entrepreneurship program in secondary schools. Ph.D. Thesis Universiti Putra Malaysia.

al-Qaradawi, Yusuf. 1990. Al-Iman wa al-hayah. Al-Qahirah: Maktabah al-Wahbah.

al-Qaradawi, Yusuf. n.d. Sports in Islam.http :/ / www.taranime.com / vb / showthread.php (10 March 2011).

Ibn.Saqr, cAtiyya.2009. Sport in Islam. http://www.ams-sa.org/articles/58-sport/79-sport-in-islam-html [15 March 2011].

Ibn.Saqr, cAtiyya. 2010. Sport and Islam ... Relationship of Religion and Ethics of sport sportscar. http://www.i7ur.com/vb/t15156. html\&prev [10 March 2011].

Sekaran, Uma. 2003. Research methods for business: A skill building approach. United Kingdom: Pergament Press.

Torres C. S., Madeline M. Suva, Lynette B. Carpio, Winifredo B. Dagli. 2006. Public Understanding and Perception of Agricultural Biotechnology and AttitudeTowards in the Philippines. College of Development Communication University of the Philippines Los Baños.

Uriya Shavit \& Ofir Winter. 2011. Sports in contemporary Islamic law. Islamic Law and Society. 18: 250-280.

Zimmerman, B.J. 1989a. Models of self-regulated learning and Academic Achievement. INSIDE. B.J. Zimmerman \& D.H. SCHUNK (pnyt.). Self-regulated learning and Academic Achievement: theory, research and practice, p. 1-25. New York: Springer-Verlag.

Zimmerman, B.J. 1989b. A social cognitive view of self-regulated learning.Journal of Educational Psychology. 81 (3): 329-339.

Zimmerman, B.J. 2000a. Attaining self-regulation: a social cognitive perspective. INSIDE. M. Boekaerts, P.R. Pintrich \& M. Zeidner (pnyt.). Handbook of Self-regulation, p. 13-35. San Diego, CA: Academic Press. 